\title{
Impacts of two introduced suspension feeders in Port Phillip Bay, Australia
}

\author{
D. Jeff Ross ${ }^{1, *}$, Michael J. Keough ${ }^{1}$, Andy R. Longmore ${ }^{2}$, Nathan A. Knott ${ }^{1}$ \\ ${ }^{1}$ Department of Zoology, University of Melbourne, Melbourne, Victoria 3010, Australia \\ ${ }^{2}$ Marine and Freshwater Systems, Primary Industries Research Victoria, Queenscliff, Victoria 3225, Australia
}

\begin{abstract}
In the past decade there has been a rapid increase in the study of the ecological consequences of marine invasions, but we still have data for only a small proportion of established marine invaders. This is exemplified by Port Phillip Bay, Australia, for which we have quantitative data on the impacts of only a handful of the $>160$ introduced and cryptogenic species present. Some of the most conspicuous of these invaders are the large epibenthic suspension feeders living on soft sediments. In this study, we examined the impact of 2 of the most common epibenthic suspension feeders in Port Phillip Bay, the introduced polychaete Sabella spallanzanii and an introduced solitary ascidian, Styela clava, by manipulating their densities in the field across the range of naturally occurring densities. Because of their physical presence at the sediment-water interface and suspension feeding activities, we predicted varying impacts across different macrofaunal groups (suspension feeders, deposit feeders, recruits and mobile species). These predictions were not supported for either introduced species despite good power. For individual taxa, there was a significant negative relationship between Sabella density and the abundance of lumbrinerid polychaetes and gammarid amphipods, and between Styela density and the abundance of lumbrinerids, tanaids, crustaceans as a group, and the bivalve Laternula rostrata. Nonetheless, these taxa only represent a small proportion of those present, and importantly, the effects generally emerged at Sabella and Styela densities ( $>1$ to 2 ind. $\mathrm{m}^{-2}$ ) greater than those typically recorded on Port Phillip Bay sediments. Therefore, we suggest that the effects of Sabella and Styela on soft sediment assemblages in Port Phillip Bay are likely to be negligible.
\end{abstract}

KEY WORDS: Introduced species · Suspension feeders - Density manipulation · Soft sediments · Epibenthic

\section{INTRODUCTION}

Human-mediated biological introductions are recognised as one of the top 5 threats to native biodiversity (Elton 1958, Carlton 1989, Vitousek et al. 1996). The catastrophic ecological impacts of introduced species such as the Asian clam Potamocorbula amurensis in San Francisco Bay (Nichols et al. 1990) and the comb jelly Mnemiopsis leidyi in the Black Sea (Shushkina \& Musayeva 1990) have highlighted the significance of introduced species in the marine environment (including bays, estuaries, and open coasts). Although there has been a rapid increase in the study of the ecological consequences of marine invasions in the past decade (e.g. Crooks 1998, Crooks \& Khim 1999, Grosholz et al. 2000, Talley et al. 2001, Ross et al. 2002, 2003, Wonham et al. 2005), this represents only a small proportion of established marine invaders. In most cases, we rely on inferences based on the invader's density and limited knowledge of its ecology (Ruiz et al. 1997, Thresher 1999).

While the extent of invasions is not well known in most cases, Port Phillip Bay in southern Australia is one of the most thoroughly investigated in the world (Hewitt et al. 2004). Over 160 introduced and cryptogenic species covering a broad range of taxonomic and 
trophic groups and habitats have been identified (Hewitt et al. 2004). Some of the most conspicuous of these invaders are the large $(>2 \mathrm{~cm})$ sessile species that live on soft sediments. These include the European fanworm Sabella spallanzanii and the 4 solitary ascidians Ascidiella aspersa, Styela clava, Styela plicata and Ciona intestinalis. In a survey of Port Phillip Bay in 1998, these 5 species accounted for more than one third of all the epibenthic individuals collected (Cohen et al. 2000).

Species that modify local habitat characteristics can substantially affect populations of associated species (see Bruno \& Bertness 2001). Not surprisingly, habitat alteration is now recognised as one of the most important mechanisms of invader impacts (Crooks 2002a). Because of their physical presence at the sedimentwater interface, Sabella spallanzanii and the 4 ascidians (Ascidiella aspersa, Styela clava, Styela plicata and Ciona intestinalis) have the potential to cause major changes to native assemblages. They could alter water flow over the seabed, facilitating the settlement and recruitment of larvae (Eckman 1983, Snelgrove et al. 1993). However, if they reach high enough densities, it is possible that they may prevent larvae reaching the sediments by inducing skimming flow, similar to that noted by Green et al. (1998) over beds of the suspension feeding bivalve Atrina zelandica. The structural complexity created by their tubes/tests may also provide a refuge from predation and lower the foraging efficiency of predators (Woodin 1978, Peterson \& Black 1993). Structural complexity, however, has also been shown to facilitate predation (Micheli 1997). Their biological activities also have the potential to influence the structure of macrofaunal assemblages; suspensionfeeding can deplete the water column of food and larvae (Woodin 1976, Peterson \& Black 1987, Petersen \& Riisgard 1992, Andre et al. 1993), and the deposition of faecal material may change the biogeochemical composition of their surrounding sediments (Klerks et al. 1996, Peterson \& Heck 1999).

Despite the potential for the introduced fanworm and ascidians to cause major changes in the structure of native assemblages in Port Phillip Bay, their impacts remain largely unknown. Although we have good quantitative data on the impacts of Sabella spallanzanii on assemblages living on hard substrates (Holloway \& Keough 2002a,b), its impacts have not been assessed for assemblages in soft sediments, even though soft sediments are the predominant benthic habitat in Port Phillip Bay (Greilach et al. 1997). Here, we describe the results of a manipulative experiment to investigate the impacts of Sabella spallanzanii (hereafter also referred to as Sabella) and the ascidian Styela clava (hereafter also referred to as Styela) on soft sediment assemblages. In an extensive review of introduced species impacts in Chesapeake Bay, Ruiz et al. (1999) suggested that spatio-temporal variability in impacts stems primarily from space-time patterns of density of the introduced species. Because the densities of both of these species have varied considerably in space and time since they were first discovered in Port Phillip Bay, density treatments were incorporated that covered the range of densities that have been recorded for both species.

We predicted that our density manipulations would affect the structure of native assemblages in a combination of the following ways: (1) the abundance of suspension feeders would decrease with increasing Sabella and Styela density as a result of increasing competition for food; (2) the abundance of deposit feeders would increase with the density of Sabella and Styela due to an increase in food availability from Sabella and Styela biodeposits; (3) the abundance of mobile species would increase with increasing Sabella and Styela density due to an added refuge from predators, and (4) the abundance of juveniles would change with increasing Sabella and Styela density due to consumption of larvae by the suspension feeders, altered water flow around their tubes/tests, or changed colonization by newly settled individuals.

\section{MATERIALS AND METHODS}

Study species. Sabella spallanzanii (Gmelin, 1791), a native of the Mediterranean and the Atlantic east coast, has been introduced to several locations throughout the world, including a number of harbours along the southern coast of Australia. It was first reported in Australian waters in the Geelong arm of Port Phillip Bay, Victoria, in the late 1980s where it has since spread to occupy much of the Bay (Carey \& Watson 1992, Parry et al. 1996, Cohen et al. 2000). This large, sessile fanworm, with a tube that can reach $40 \mathrm{~cm}$ in length and a spiral feeding fan up to 10 to $15 \mathrm{~cm}$ in diameter, colonises both hard and soft substrata (Holloway \& Keough 2002a). On soft substrata it is often found attached to a hard object on the sediment surface such as the solitary ascidian Pyura stolonifera, oysters, scallops or conspecific tubes. However, it also commonly occurs with the base of the tube buried in the sediment (10 to $15 \mathrm{~cm}$ ). These tubes have a pronounced U-shaped bend at their base, which may function as an anchor (Parry et al. 1996). Densities of Sabella up to 13 ind. $\mathrm{m}^{-2}$ have been recorded on soft sediments over large areas $\left(\sim 50 \mathrm{~m}^{2}\right)$, and up to 200 to 300 ind. in concentrated patches or clumps $\left(<1 \mathrm{~m}^{2}\right)$ (Parry et al. 1996). In recent years densities of Sabella appear to have declined to relatively low levels (0 to 1 ind. $\mathrm{m}^{-2}$; Cohen et al. 2000, D. J. Ross unpubl. data) 
compared with the period following its initial establishment and expansion in the late 1980s to mid-1990s (1 to 5 ind. $\mathrm{m}^{-2}$; Parry et al. 1996).

Styela clava (Herdman, 1881) is a northwestern Pacific species that has been introduced to many parts of the world including Port Phillip Bay. It was first described in Australia by Holmes (1976), from material collected in Port Phillip Bay in 1972. It is a solitary ascidian with a roughened test generally growing on a short (usually $<7 \mathrm{~cm}$ ) stalk found on both hard and soft substrata. Present throughout Port Phillip Bay on soft sediments, it generally occurs at low densities (0 to 0.2 ind. $\left.\mathrm{m}^{-2}\right)$ over large areas $\left(\sim 50 \mathrm{~m}^{2}\right.$; Cohen et al. 2000) and up to 2 to 5 individuals in concentrated patches $\left(\sim 1 \mathrm{~m}^{2}\right.$; D. J. Ross pers. obs.).

Background. The experiment was undertaken at Point Wilson (38 $07^{\prime} \mathrm{S}, 144^{\circ} 32^{\prime} \mathrm{E}$ ) in the Geelong arm of Port Phillip Bay, Victoria, Australia, at a depth of $11 \mathrm{~m}$. The sediment at the site is composed predominately of silt to very fine sand. The average density of Sabella spallanzanii recorded at this site at the start of the experiment was 0.47 ind. $\mathrm{m}^{-2}( \pm 0.04 \mathrm{SE})$. Styela was present in the area, but at very low densities. The experiment ran for $10 \mathrm{wk}$, starting in late August 2001.

Experimental design. Because the densities of both species are highly variable in space and time, our aim was to examine their effects on soft sediment assemblages at a range of densities. Experimental plots consisted of a $2 \times 2 \mathrm{~m}$ area containing one of the following treatments: control (no Sabella or Styela added); Sabella added at $0.5,2,5$ and $10 \mathrm{~m}^{-2}$ or Styela added at $0.5,2$ and $5 \mathrm{~m}^{-2}$. Each treatment was replicated 5 times. The 40 plots were arranged in a grid pattern with $5 \mathrm{~m}$ separating each plot, and then allocated randomly to treatments.

Both species were collected from a location approximately $200 \mathrm{~m}$ from the experimental area and kept in a seawater-filled well on a boat for no longer than $1 \mathrm{~h}$ while all fauna was cleared off the tubes. Sabella and Styela were randomly assigned to the experimental plots, and then haphazardly distributed within each plot. Sabella were inserted into the sediment using tweezers so that the U-shaped bend at the base of the tube was 100 to $150 \mathrm{~mm}$ below the sediment surface, leaving the remainder of the tube $(>200 \mathrm{~mm}$ ) protruding above the sediment surface. Styela are predominately found attached to hard substrata on the sediment surface rather than partially buried in the sediment. Individuals were therefore attached to wooden sticks (200 mm long, $2 \mathrm{~mm}$ diameter) using a cable tie at the base of the stalk. The sticks were then inserted into the sediments so that the ascidian was in an upright position with the base of the stalk flush with the sediment surface and $<30 \mathrm{~mm}$ of the stick protruding above the sediment surface. A census of the num- ber of alive and dead Sabella and Styela was conducted $2 \mathrm{wk}$ after the start of the experiment to ensure that the translocation process had been successful.

Sampling of invertebrates. At the end of the experiment the number of alive and dead Sabella and Styela in each plot was counted. Two sediment samples were then taken from each plot to estimate the abundance of macro-invertebrates. To do this, 2 metal cylinders $(35.5 \mathrm{~cm}$ in diameter $\times 20 \mathrm{~cm}$ long) were inserted into the sediment to a depth of $15 \mathrm{~cm}$. The contents of each cylinder were vacuumed to a depth of $10 \mathrm{~cm}$ into the same $1 \mathrm{~mm}$ mesh bag using a diver-operated, waterdriven suction device, creating a single large sample (total area sampled $0.2 \mathrm{~m}^{2}$ ) for each plot. Samples were then stained with rose bengal and frozen prior to sorting. Samples were then sieved through 2.8 and $1 \mathrm{~mm}$ mesh. All infaunal and epifaunal organisms retained on the $2.8 \mathrm{~mm}$ mesh sieve were sorted and identified to the lowest possible taxon. All material retained on the $1 \mathrm{~mm}$ mesh sieve was split into quarters using a 'Jones' type sediment splitter and all infaunal and epifaunal organisms in 2 of these subsamples were sorted to the lowest possible taxon. Compositing samples in the field followed by sub-sampling in the laboratory allowed us to sample a larger area, and thus, obtain more reliable abundance estimates for each plot without increasing the time required to process the samples (see Carey \& Keough 2002).

Statistical analysis. Univariate: The responses of numerically dominant taxa to experimental treatments were analysed using analysis of variance (ANOVA) and linear regression. Inspection of box plots and residuals revealed that a $\log (x+0.01)$ transformation improved the homogeneity of variances, and this was used for the entire data set. Tests for Sabella and Styela effects were conducted separately. Because the treatment densities had changed (decreased) by the end of the experiment for both Sabella and Styela it was decided to use the initial or final densities in the analysis. We present results of the 2 alternative analyses: (1) one-way analysis of variance (ANOVA) with initial density as the categorical variable, and (2) linear regression analysis with final density as a continuous variable. Following the ANOVA, planned comparisons were conducted to identify significant linear or quadratic relationships among the 5 treatments spaced according to density (i.e. $0,0.5,2,5$ and $10 \mathrm{~m}^{-2}$ ). Because there were few significant treatment effects, particularly for Sabella, we calculated the power to detect a $50 \%$ and $80 \%$ change in abundance between the control and a density of 10 ind. $\mathrm{m}^{-2}$ for the ANOVA and regression analysis. These power calculations were done using PiFace, a power analysis add-in for Microsoft Excel (available at: www.stat.uiowa.edu/ftp/ rlenth/PiFace/). 
Multivariate: The PRIMER v4.0 computer program (Clarke 1993) was used for comparison of assemblage composition. To depict differences in the structure of whole assemblages across the treatment densities, non-metric multidimensional scaling (nMDS) was done on Bray-Curtis distances calculated from fourth root transformed data. Tests of differences in the structure of assemblages between treatment densities were done using analysis of similarities (ANOSIM) .

\section{RESULTS}

Although the number of Sabella spallanzanii and Styela clava in each treatment, particularly in the high density treatments, had decreased substantially by the end of the experiment (Tables $1 \& 2$ ), there were still significant differences between treatments using the final densities (Sabella $F_{4,19}=7.50, \mathrm{p}=0.001$; Styela $\left.F_{3,16}=36.12, \mathrm{p}<0.001\right)$. The major groups found in the sediment samples at Point Wilson were bivalves, crustaceans, echinoderms, gastropods and polychaetes that represented $60,18,15,4$ and $3 \%$, respectively, of the total numerical abundance. The most abundant taxa in decreasing order of abundance were the bivalve Theora lubrica, brittle stars, diastylid cumaceans, the bivalve Fulvia tenuicostata, amphipods, the opisthobranch gastropod Retusa pelyx, the bivalve Laternula rostrata, holothurians, ostracods, the echinoid Echinocardium cordatum, and polychaetes in the families Lumbrineridae and Terebellidae. Because of the large number of taxa and groups, reported data were restricted to the macrofaunal groups for which we had made a priori predictions, and those taxa for which there was a significant treatment effect. The molluscs were the only group with substantial numbers of juveniles to test prediction (4) that the abundance of juveniles would change with increasing Sabella and Styela density.

\section{Sabella spallanzanii effects}

Lumbrinerid polychaetes and gammarid amphipods were the only taxa for which there was a significant Sabella effect. Although the decline in abundance of lumbrinerids and gammarids was evident using either initial or final Sabella densities (Figs. 1 \& 2), the relationship was significant only using initial densities for lumbrinerids $\left(\mathrm{p}_{\text {initial }}=0.047, \mathrm{p}_{\text {final }}=0.104\right.$; Table 3$)$ and

Table 1. Sabella spallanzanii. Mean abundances \pm SE per sample $\left(0.2 \mathrm{~m}^{2}\right)$ of major taxa and groups found in each Sabella density treatment

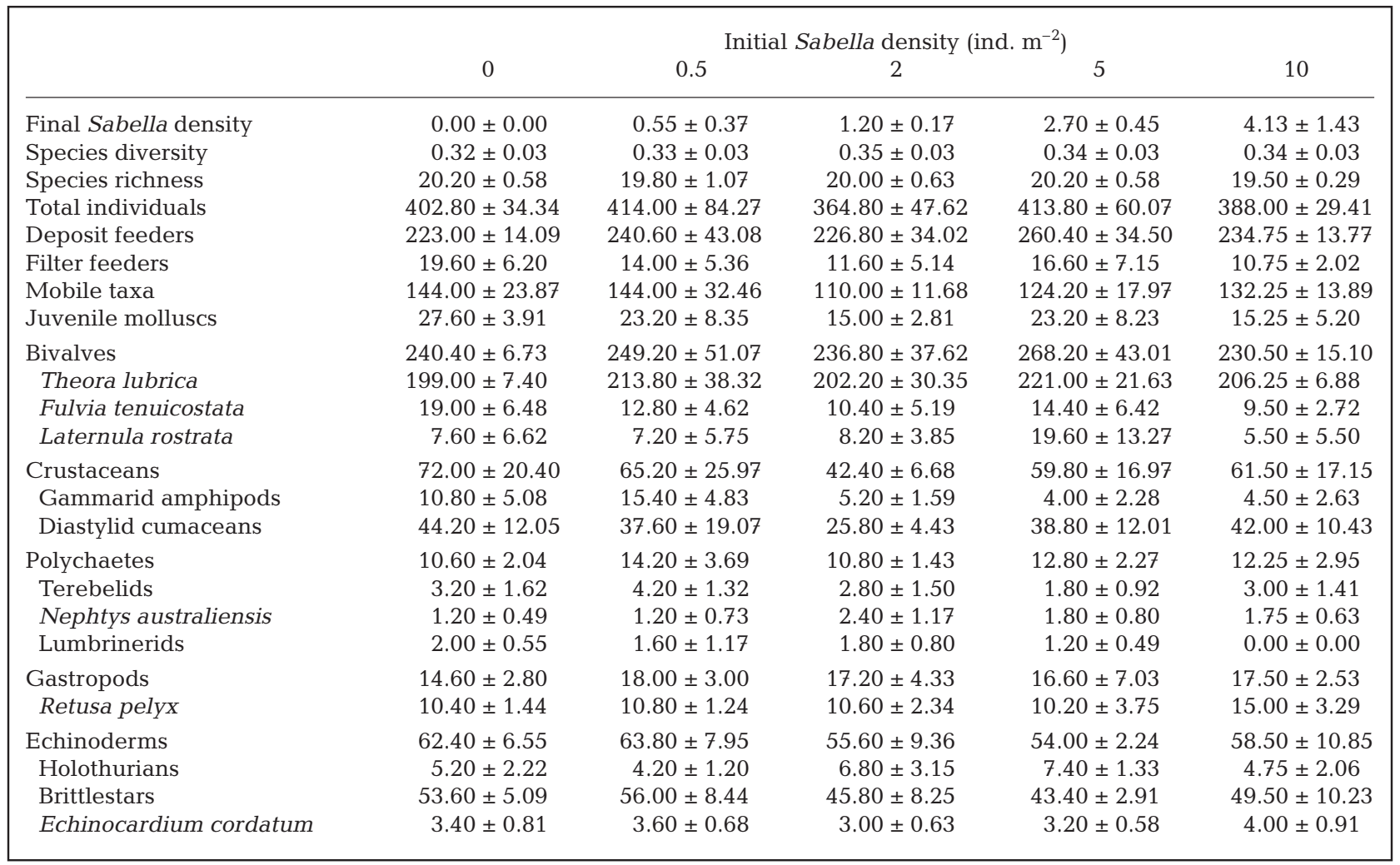


Table 2. Styela clava. Mean abundances \pm SE per sample $\left(0.2 \mathrm{~m}^{2}\right)$ of major taxa and groups found in each Styela density treatment

\begin{tabular}{|c|c|c|c|c|}
\hline & \multicolumn{4}{|c|}{ Initial Styela density (ind. $\mathrm{m}^{-2}$ ) } \\
\hline & 0 & 0.5 & 2 & 5 \\
\hline Final Styela density & $0.00 \pm 0.00$ & $0.40 \pm 0.06$ & $1.65 \pm 0.13$ & $2.80 \pm 0.40$ \\
\hline Species diversity & $0.32 \pm 0.03$ & $0.30 \pm 0.06$ & $0.30 \pm 0.02$ & $0.29 \pm 0.06$ \\
\hline Species richness & $23.20 \pm 0.73$ & $23.00 \pm 1.26$ & $24.80 \pm 0.49$ & $21.80 \pm 0.58$ \\
\hline Total individuals & $402.80 \pm 34.34$ & $420.00 \pm 55.19$ & $484.80 \pm 48.18$ & $330.40 \pm 56.24$ \\
\hline Deposit feeders & $223.00 \pm 14.09$ & $237.20 \pm 41.23$ & $285.20 \pm 29.92$ & $184.00 \pm 52.19$ \\
\hline Filter feeders & $19.80 \pm 6.15$ & $15.20 \pm 4.29$ & $34.00 \pm 6.86$ & $22.60 \pm 5.27$ \\
\hline Mobile taxa & $144.00 \pm 23.87$ & $144.80 \pm 26.36$ & $142.60 \pm 10.83$ & $117.00 \pm 11.60$ \\
\hline Juvenile molluscs & $27.60 \pm 3.91$ & $22.00 \pm 5.48$ & $46.80 \pm 6.72$ & $29.00 \pm 4.81$ \\
\hline Bivalves & $240.40 \pm 6.73$ & $244.40 \pm 43.08$ & $314.60 \pm 35.72$ & $199.40 \pm 53.50$ \\
\hline Theora lubrica & $199.00 \pm 7.40$ & $199.00 \pm 34.07$ & $242.00 \pm 18.25$ & $168.20 \pm 51.31$ \\
\hline Fulvia tenuicostata & $19.00 \pm 6.48$ & $13.40 \pm 4.20$ & $27.60 \pm 6.09$ & $21.20 \pm 5.80$ \\
\hline Laternula rostrata & $7.60 \pm 6.62$ & $18.40 \pm 10.76$ & $22.00 \pm 12.20$ & $0.40 \pm 0.40$ \\
\hline Crustaceans & $72.00 \pm 20.40$ & $98.00 \pm 22.82$ & $62.00 \pm 10.61$ & $42.40 \pm 5.05$ \\
\hline Gammarid amphipods & $10.80 \pm 5.08$ & $13.60 \pm 3.96$ & $10.20 \pm 1.28$ & $5.60 \pm 1.94$ \\
\hline Diastylid cumaceans & $44.20 \pm 12.05$ & $60.20 \pm 15.27$ & $40.00 \pm 11.22$ & $29.20 \pm 3.72$ \\
\hline Cylindroleberidae ostracods & $2.80 \pm 1.20$ & $3.60 \pm 1.83$ & $2.80 \pm 1.20$ & $2.60 \pm 0.87$ \\
\hline Tanaids & $2.20 \pm 0.37$ & $1.80 \pm 0.58$ & $0.80 \pm 0.49$ & $0.60 \pm 0.40$ \\
\hline Mysids & $5.40 \pm 4.47$ & $6.40 \pm 4.17$ & $4.00 \pm 1.26$ & $0.40 \pm 0.40$ \\
\hline Polychaetes & $10.60 \pm 2.04$ & $18.00 \pm 2.98$ & $17.00 \pm 3.41$ & $12.00 \pm 3.61$ \\
\hline Trichobranchids & $3.20 \pm 1.62$ & $2.20 \pm 1.02$ & $3.20 \pm 1.50$ & $2.60 \pm 1.29$ \\
\hline Nephtys australiensis & $1.20 \pm 0.49$ & $2.00 \pm 1.26$ & $2.40 \pm 0.51$ & $3.40 \pm 1.40$ \\
\hline Lumbrinerids & $2.00 \pm 0.55$ & $3.60 \pm 1.54$ & $2.60 \pm 0.40$ & $0.40 \pm 0.40$ \\
\hline Gastropods & $14.60 \pm 2.80$ & $15.80 \pm 3.62$ & $20.60 \pm 5.18$ & $19.00 \pm 2.90$ \\
\hline Retusa pelyx & $10.40 \pm 1.44$ & $9.40 \pm 3.09$ & $8.60 \pm 2.11$ & $11.80 \pm 3.60$ \\
\hline Echinoderms & $62.40 \pm 6.55$ & $42.00 \pm 12.05$ & $68.20 \pm 4.81$ & $54.40 \pm 6.71$ \\
\hline Holothurians & $5.20 \pm 2.22$ & $8.40 \pm 3.64$ & $9.80 \pm 3.54$ & $4.40 \pm 1.44$ \\
\hline Brittlestars & $53.60 \pm 5.09$ & $28.60 \pm 8.93$ & $55.40 \pm 5.05$ & $47.00 \pm 7.71$ \\
\hline Echinocardium cordatum & $3.40 \pm 0.81$ & $4.80 \pm 1.32$ & $2.80 \pm 0.92$ & $2.60 \pm 1.25$ \\
\hline
\end{tabular}

final densities for gammarids $\left(\mathrm{p}_{\text {initial }}=0.099, \mathrm{p}_{\text {final }}=\right.$ 0.030; Table 3). Of the remaining taxa for which there was no significant change in abundance with Sabella density, power to detect a $50 \%$ and $80 \%$ change in abundance between the control and 10 Sabella $\mathrm{m}^{-2}$ was high ( $\geq 0.8)$ for $36 \%$ and $62 \%$ of taxa respectively, using the initial densities. When using final densities, the power to detect a $50 \%$ and $80 \%$ change in abundance between the control and 10 Sabella $\mathrm{m}^{-2}$ was high $(\geq 0.8)$ for $10 \%$ and $50 \%$ of the taxa respectively. Not surprisingly, given the lack of significant Sabella effects on individual taxa, there was no evidence of assemblage level effects in the ordination (MDS) (Fig. 3a). The multivariate analysis of variance between the treatment densities confirmed there was no evidence of assemblage level effects (ANOSIM: global $\mathrm{R}=-0.052$, $\mathrm{p}=0.769$ ).

\section{Styela clava effects}

There was a significant relationship between the abundance of lumbrinerids, tanaids, crustaceans as a group, and the bivalve Laternula rostrata and Styela density (Table 4, Figs. 4 \& 5). For tanaids and crustaceans as a group, this relationship was linear, with abundances declining with increasing Styela density. For the bivalve Laternula rostrata the relationship was quadratic, with abundance increasing to its highest in the 2 Styela $\mathrm{m}^{-2}$ treatment before declining to its lowest in the 5 Styela $\mathrm{m}^{-2}$ treatment. For lumbrinerid polychaetes there was both a significant linear and quadratic relationship with Styela density. The relationship was significant using either final or initial Styela densities for tanaids and lumbrinerids, but for crustaceans and Laternula the relationship with initial, and not final, density was significant. In the case of Laternula this is probably reflected by the use of a linear regression in the analysis of final densities, which will not detect the modal (quadratic) response. For the remaining taxa and groups, the power to detect a $50 \%$ or $80 \%$ change in abundance between the control and 10 Styela $\mathrm{m}^{-2}$ was low (with the exception of species richness) when testing for a linear relationship. In contrast, there was reasonable power $(\geq 0.8)$ to detect an $80 \%$ change in abundance between the control and 

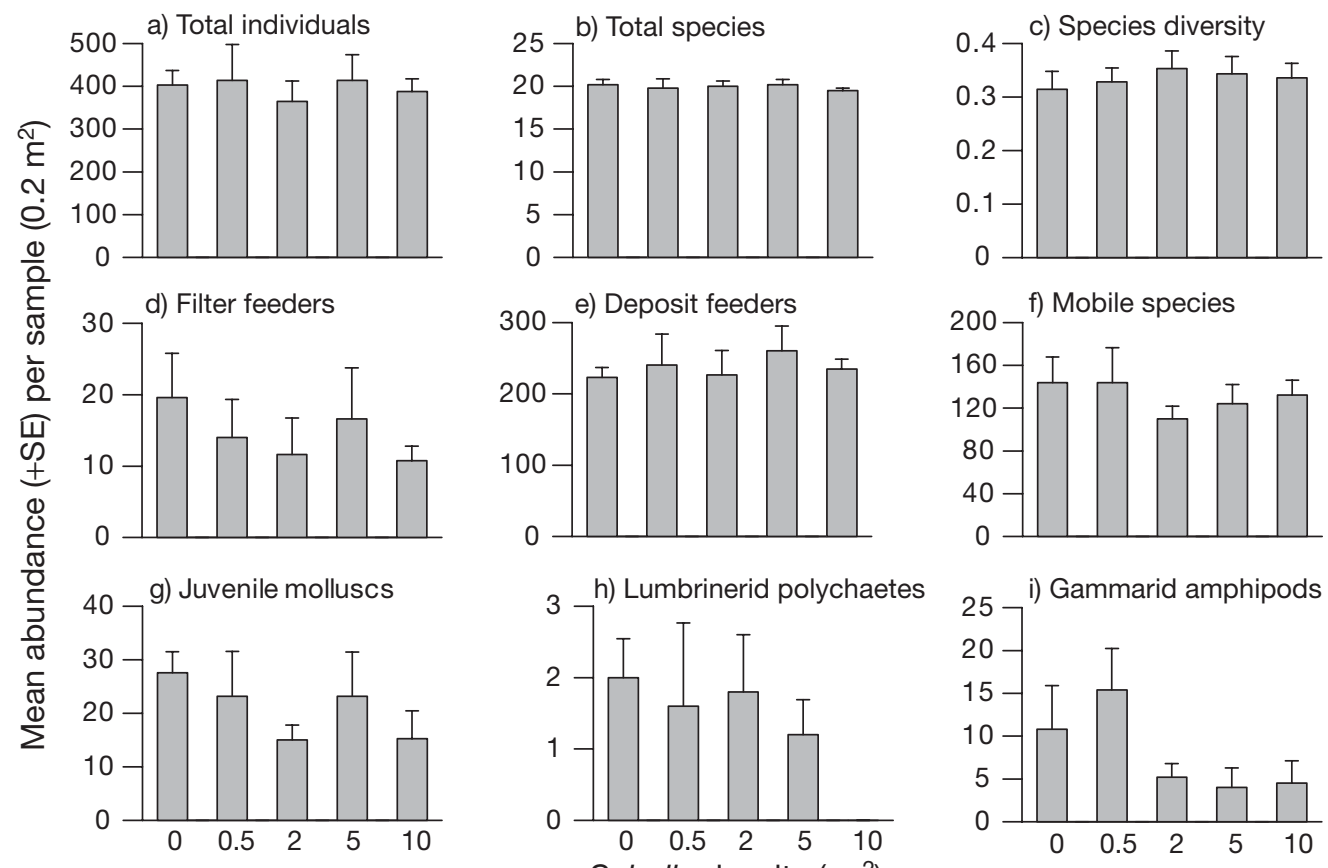

Fig. 1. Sabella spallanzanii. Mean abundances + SE per sample $\left(0.2 \mathrm{~m}^{2}\right)$ of the major taxa and groups found in each Sabella density treatment
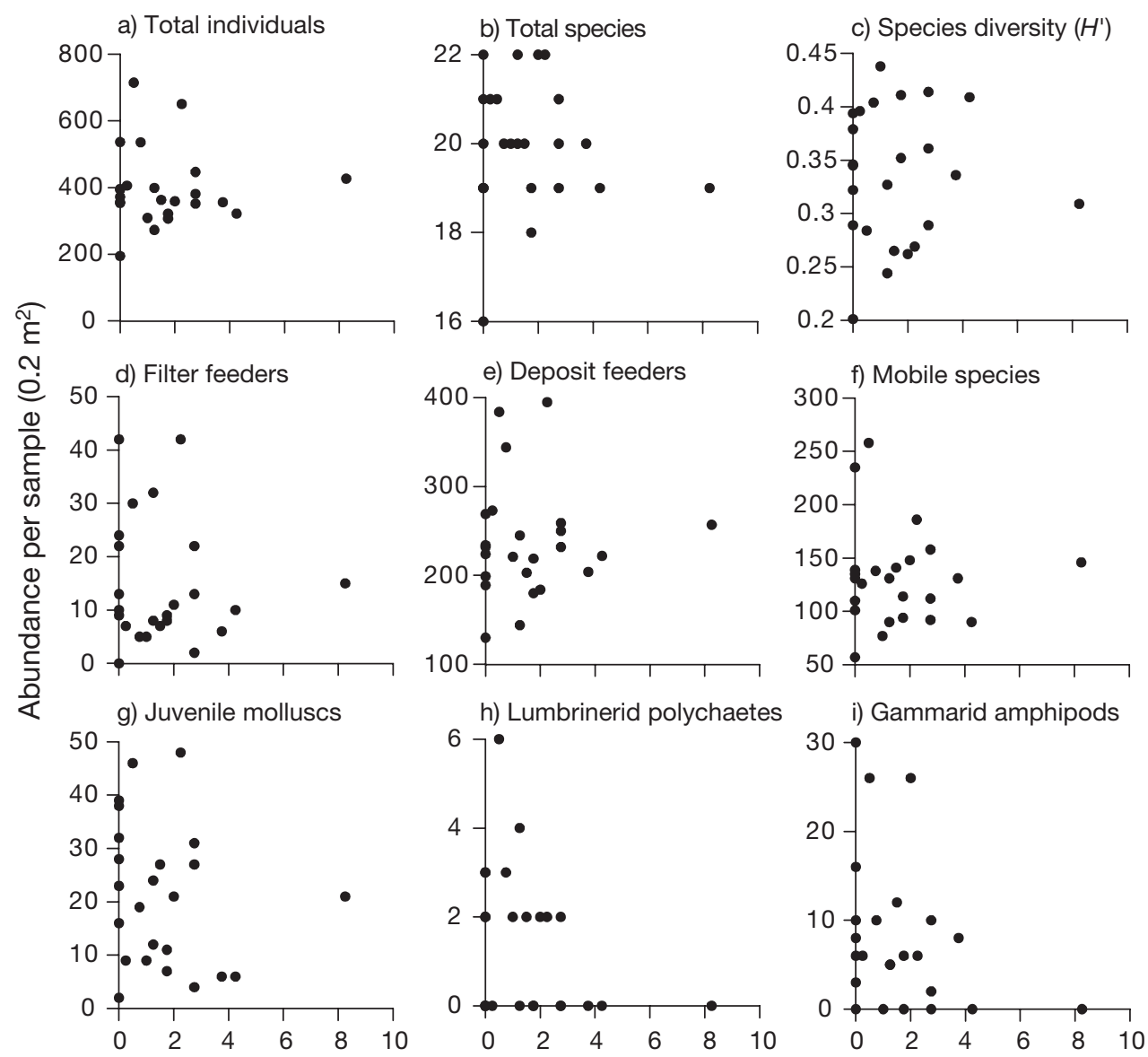

Final Sabella density $\left(\mathrm{m}^{-2}\right)$

Fig. 2. Sabella spallanzanii. Abundance per sample $\left(0.2 \mathrm{~m}^{2}\right)$ of the major taxa and groups against the final density of Sabella in each experiment plot 
Table 3. Sabella spallanzanii. Analysis of variance results of planned comparisons to identify significant linear or quadratic relationships among the 5 Sabella treatments spaced according to the initial treatment density (i.e. 0, 0.5, 2, 5 and 10 ind. $\mathrm{m}^{-2}$ ) and the abundance of the most common taxa. Linear regression analysis between the number of Sabella in plots remaining at the end of the experiment and the abundance of the most common taxa. Power calculations are based on a 50 and $80 \%$ change from the control to 10 Sabella $\mathrm{m}^{-2}$ for both the ANOVA and regression analysis. Data were transformed to $x^{\prime}=\log _{\mathrm{e}}(x+0.01)$. Significant $\mathrm{p}$-values are shown in bold

\begin{tabular}{|c|c|c|c|c|c|c|c|c|c|c|c|}
\hline & \multirow{3}{*}{$\mathrm{MS}_{\text {resid }}$} & \multirow{3}{*}{$\mathrm{p}_{\text {linear }}$} & \multicolumn{3}{|c|}{ ANOVA } & \multirow{2}{*}{\multicolumn{2}{|c|}{ Power }} & \multicolumn{4}{|c|}{ Regression analysis } \\
\hline & & & \multicolumn{2}{|c|}{ Power } & \multirow{2}{*}{$\mathrm{p}_{\text {quadratic }}$} & & & \multirow[t]{2}{*}{$\mathrm{R}$} & \multirow[t]{2}{*}{$\mathrm{p}$} & \multicolumn{2}{|c|}{ Power } \\
\hline & & & 50 & 80 & & 50 & 80 & & & 50 & 80 \\
\hline Degrees of freedom & 19 & 1 & & & 1 & 1 & 1 & & 1,22 & & \\
\hline Species diversity & 0.043 & 0.706 & 0.99 & 1.00 & 0.547 & 1.00 & 1.00 & 0.034 & 0.875 & 0.83 & 1.00 \\
\hline Species richness & 0.006 & 0.682 & 1.00 & 1.00 & 0.670 & 1.00 & 1.00 & 0.057 & 0.793 & 1.00 & 1.00 \\
\hline Total individuals & 0.087 & 0.936 & 0.89 & 1.00 & 0.940 & 0.93 & 1.00 & 0.030 & 0.889 & 0.54 & 1.00 \\
\hline Deposit feeders & 0.078 & 0.643 & 0.92 & 1.00 & 0.621 & 0.96 & 1.00 & 0.097 & 0.653 & 0.58 & 1.00 \\
\hline Filter feeders & 2.841 & 0.790 & 0.07 & 0.21 & 0.998 & 0.08 & 0.25 & 0.110 & 0.610 & 0.06 & 0.13 \\
\hline Mobile taxa & 0.125 & 0.987 & 0.73 & 1.00 & 0.392 & 0.81 & 1.00 & 0.016 & 0.940 & 0.39 & 0.97 \\
\hline Juvenile molluscs & 0.746 & 0.400 & 0.15 & 0.69 & 0.728 & 0.18 & 0.78 & 0.134 & 0.533 & 0.11 & 0.36 \\
\hline Bivalves & 0.091 & 0.982 & 0.87 & 1.00 & 0.667 & 0.92 & 1.00 & 0.010 & 0.961 & 0.52 & 1.00 \\
\hline Theora lubrica & 0.071 & 0.714 & 0.95 & 1.00 & 0.743 & 0.97 & 1.00 & 0.058 & 0.788 & 0.63 & 1.00 \\
\hline Fulvia tenuicostata & 2.951 & 0.951 & 0.07 & 0.20 & 0.999 & 0.08 & 0.24 & 0.086 & 0.690 & 0.06 & 0.13 \\
\hline Laternula rostrata & 13.584 & 0.503 & 0.05 & 0.08 & 0.177 & 0.06 & 0.08 & 0.189 & 0.378 & 0.05 & 0.07 \\
\hline Crustaceans & 0.323 & 0.893 & 0.32 & 0.98 & 0.519 & 0.38 & 0.99 & 0.057 & 0.791 & 0.18 & 0.68 \\
\hline Gammarid amphipods & 9.091 & 0.099 & 0.06 & 0.09 & 0.544 & 0.06 & 0.10 & 0.444 & 0.030 & & \\
\hline Diastylid cumaceans & 0.437 & 0.451 & 0.24 & 0.91 & 0.640 & 0.28 & 0.96 & 0.020 & 0.925 & 0.14 & 0.53 \\
\hline Polychaetes & 0.239 & 0.809 & 0.43 & 1.00 & 0.752 & 0.50 & 1.00 & 0.192 & 0.370 & 0.25 & 0.84 \\
\hline Terebelids & 8.536 & 0.567 & 0.06 & 0.10 & 0.364 & 0.06 & 0.11 & 0.163 & 0.446 & 0.05 & 0.08 \\
\hline Nephtys australiensis & 9.278 & 0.499 & 0.06 & 0.09 & 0.955 & 0.06 & 0.10 & 0.274 & 0.194 & 0.05 & 0.08 \\
\hline Lumbrinerids & 7.296 & 0.047 & & & 0.410 & 0.06 & 0.12 & 0.340 & 0.104 & 0.06 & 0.08 \\
\hline Gastropods & 0.347 & 0.805 & 0.30 & 0.97 & 0.520 & 0.35 & 0.99 & 0.052 & 0.809 & 0.18 & 0.66 \\
\hline Retusa pelyx & 0.297 & 0.462 & 0.35 & 0.98 & 0.174 & 0.41 & 1.00 & 0.055 & 0.797 & 0.19 & 0.69 \\
\hline Echinoderms & 0.098 & 0.619 & 0.84 & 1.00 & 0.485 & 0.90 & 1.00 & 0.156 & 0.466 & 0.50 & 0.99 \\
\hline Holothurians & 3.954 & 0.543 & 0.07 & 0.16 & 0.453 & 0.07 & 0.19 & 0.111 & 0.607 & 0.06 & 0.11 \\
\hline Brittlestars & 0.12 & 0.534 & 0.84 & 1.00 & 0.323 & 0.90 & 1.00 & 0.134 & 0.532 & 0.40 & 0.98 \\
\hline Echinocardium cordatum & 0.243 & 0.563 & 0.57 & 1.00 & 0.590 & 0.65 & 1.00 & 0.258 & 0.224 & 0.24 & 0.84 \\
\hline
\end{tabular}

10 Styela $\mathrm{m}^{-2}$ for half of the taxa when testing for a quadratic relationship. At the assemblage level, there was no evidence of a Styela effect in the ordination (Fig. 3b) or multivariate analysis (ANOSIM: global $\mathrm{R}=0.075, \mathrm{p}=0.202$ ).

\section{DISCUSSION}

The introduced polychaete Sabella spallanzanii and ascidian Styela clava have the potential to affect the abundance of macrofauna in the surrounding sediments via 2 different mechanisms: effects caused by changes in the benthic habitat due to the physical presence of the tube or test, and those caused by their biological activities, particularly suspension feeding and biodeposition. This experiment was designed to examine their effects on a soft sediment assemblage in Port Phillip Bay, Australia at a range of densities. Lumbrinerid polychaetes and gammarid amphipods were the only taxon or group for which there was a signifi- cant Sabella effect. We would have expected this number of significant outcomes due to chance alone given that 72 tests were conducted. Although the tests on unaffected taxa and groups varied in power, there was sufficient power $(\geq 0.8)$ to detect a 50 or $80 \%$ change in abundance between the control and 10 Sabella $\mathrm{m}^{-2}$ for 36 and $62 \%$ of the major taxa and groups, respectively. Despite lower overall power to detect Styela effects, there was a significant negative relationship between Styela density and the abundance of lumbrinerids, tanaids, crustaceans as a group and the bivalve Laternula rostrata. With 81 tests conducted in total, the number of significant outcomes (7 in total) was greater than the number $(\sim 4)$ we would have expected due to chance alone.

We also made a number of specific predictions of the response of various macrofaunal groups to our density manipulations of these 2 large epibenthic suspension feeders. We predicted that the abundance of deposit feeders would increase with increasing Sabella and Styela densities due to an increase in food availability 
from Sabella and Styela biodeposits. This pattern was not evident for either introduced species despite good power. However, for the deposit feeding taxa showing an effect of the treatments (lumbrinerid polychaetes and the bivalve Laternula rostrata) there was an increase in abundance between the control and the 0.5 and 2 Styela $\mathrm{m}^{-2}$ treatments, but at the 5 Styela $\mathrm{m}^{-2}$ treatment, abundances were at their lowest. Whilst this is consistent with the prediction up to a density of 2 Styela $\mathrm{m}^{-2}$, the results suggests that other densitydependent mechanisms are more important at greater Styela densities. For suspension feeders we predicted a decrease with increasing Sabella and Styela densities as a result of increasing competition for food. There was no significant effect detected for either Sabella or Styela, but the power to detect a Sabella effect was low. Although little weight can be given to this nonsignificant result given the low power, the general decrease in abundance of suspension feeders with increasing Sabella density warrants further investigation with increased replication. We also suggested that Sabella and Styela would provide an added refuge from predation for mobile species. There was no evidence of this effect for either introduced species despite good power. Finally, we predicted that the abundance of juveniles would change with increasing Sabella and Styela density due to consumption of larvae by the suspension feeders, altered water flow around their tubes/tests, or changed colonization by newly-settled individuals. There was no evidence to suggest that either species altered the abundance of juvenile molluscs despite reasonable power to detect an $80 \%$ change in abundance between the control and a treatment density of 10 ind. $\mathrm{m}^{-2}$. The experiment needs to be repeated at other times of the year to test whether either species alters the abundance of juve-

Table 4. Styela clava. Analysis of variance results of planned comparisons to identify significant linear or quadratic relationships among the 4 Styela treatments spaced according to the initial treatment density (i.e. $0,0.5,2,5$ ind. $\mathrm{m}^{-2}$ ) and the abundance of the most common taxa. Linear regression analysis between the number of Styela in plots remaining at the end of the experiment and the abundance of the most common taxa. Power calculations are based on a $50 \%$ and $80 \%$ change from the control to 10 Styela $\mathrm{m}^{-2}$ for both the ANOVA and regression analysis. Data were transformed to $x^{\prime}=\log _{\mathrm{e}}(x+0.01)$. Significant $\mathrm{p}$-values are shown in bold

\begin{tabular}{|c|c|c|c|c|c|c|c|c|c|c|c|}
\hline & \multicolumn{7}{|c|}{ ANOVA } & \multicolumn{4}{|c|}{ Regression analysis } \\
\hline & \multirow{2}{*}{$\mathrm{MS}_{\text {resid }}$} & \multirow{2}{*}{$\mathrm{p}_{\text {linear }}$} & \multicolumn{2}{|c|}{ Power } & \multirow{2}{*}{$\mathrm{p}_{\text {quadratic }}$} & \multicolumn{2}{|c|}{ Power } & \multirow[t]{2}{*}{$\mathrm{R}$} & \multirow[t]{2}{*}{$\mathrm{p}$} & \multicolumn{2}{|c|}{ Power } \\
\hline & & & 50 & 80 & & 50 & 80 & & & 50 & 80 \\
\hline Degrees of freedom & 16 & 1 & & & 1 & & & & 2,16 & & \\
\hline Species diversity & 0.103 & 0.637 & 0.10 & 0.21 & 0.964 & 0.67 & 1.00 & 0.261 & 0.266 & 0.12 & 0.31 \\
\hline Species richness & 0.007 & 0.280 & 0.98 & 1.00 & 0.065 & 1.00 & 1.00 & 0.258 & 0.273 & 0.94 & 1.00 \\
\hline Total individuals & 0.077 & 0.135 & 0.18 & 0.71 & 0.092 & 0.81 & 1.00 & 0.370 & 0.108 & 0.20 & 0.74 \\
\hline Deposit feeders & 0.177 & 0.154 & 0.10 & 0.40 & 0.123 & 0.42 & 1.00 & 0.416 & 0.068 & 0.12 & 0.43 \\
\hline Mobile taxa & 0.494 & 0.483 & 0.07 & 0.19 & 0.165 & 0.17 & 0.73 & 0.097 & 0.686 & 0.07 & 0.17 \\
\hline Filter feeders & 0.104 & 0.365 & 0.14 & 0.71 & 0.592 & 0.66 & 1.00 & 0.127 & 0.593 & 0.17 & 0.66 \\
\hline Juvenile molluscs & 0.295 & 0.463 & 0.08 & 0.34 & 0.103 & 0.26 & 0.93 & 0.166 & 0.484 & 0.08 & 0.23 \\
\hline Bivalves & 0.160 & 0.198 & 0.11 & 0.65 & 0.105 & 0.46 & 1.00 & 0.377 & 0.101 & 0.12 & 0.45 \\
\hline Bivalve recruits & 0.363 & 0.683 & 0.07 & 0.44 & 0.122 & 0.21 & 0.85 & 0.037 & 0.876 & 0.08 & 0.20 \\
\hline Theora lubrica & 0.199 & 0.185 & 0.09 & 0.76 & 0.185 & 0.37 & 0.99 & 0.410 & 0.073 & 0.11 & 0.41 \\
\hline Fulvia tenuicostata & 0.718 & 0.716 & 0.06 & 0.26 & 0.292 & 0.13 & 0.54 & 0.018 & 0.939 & 0.07 & 0.14 \\
\hline Laternula rostrata & 7.982 & 0.052 & 0.05 & 0.07 & 0.012 & & & 0.303 & 0.194 & 0.05 & 0.06 \\
\hline Crustaceans & 0.184 & 0.027 & & & 0.699 & 0.40 & 0.99 & 0.426 & 0.061 & 0.11 & 0.38 \\
\hline Gammarid amphipods & 2.797 & 0.894 & 0.05 & 0.11 & 0.250 & 0.07 & 0.16 & 0.014 & 0.953 & 0.05 & 0.07 \\
\hline Diastylid cumaceans & 0.287 & 0.148 & 0.08 & 0.74 & 0.983 & 0.26 & 0.93 & 0.319 & 0.170 & 0.09 & 0.28 \\
\hline Cylindroleberidae ostracods & 10.303 & 0.637 & 0.05 & 0.06 & 0.844 & 0.05 & 0.08 & 0.001 & 0.998 & 0.05 & 0.06 \\
\hline Tanaids & 5.49 & 0.035 & & & 0.167 & 0.06 & 0.10 & 0.521 & 0.018 & & \\
\hline Mysids & 10.373 & 0.255 & 0.05 & 0.07 & 0.127 & 0.06 & 0.08 & 0.153 & 0.519 & 0.05 & 0.06 \\
\hline Polychaetes & 0.274 & 0.441 & 0.08 & 0.47 & 0.126 & 0.28 & 0.94 & 0.210 & 0.374 & 0.09 & 0.26 \\
\hline Trichobranchids & 6.317 & 0.746 & 0.05 & 0.07 & 0.308 & 0.06 & 0.09 & 0.045 & 0.850 & 0.05 & 0.06 \\
\hline Nephtys australiensis & 6.898 & 0.219 & 0.05 & 0.07 & 0.279 & 0.06 & 0.09 & 0.221 & 0.349 & 0.05 & 0.06 \\
\hline Lumbrinerids & 3.195 & 0.002 & & & 0.024 & & & 0.505 & 0.023 & & \\
\hline Gastropods & 0.375 & 0.382 & 0.07 & 0.37 & 0.798 & 0.20 & 0.83 & 0.213 & 0.366 & 0.08 & 0.24 \\
\hline Retusa pelyx & 2.841 & 0.642 & 0.05 & 0.12 & 0.823 & 0.08 & 0.22 & 0.059 & 0.805 & 0.05 & 0.07 \\
\hline Echinoderms & 3.701 & 0.531 & 0.05 & 0.08 & 0.872 & 0.06 & 0.13 & 0.147 & 0.537 & 0.05 & 0.07 \\
\hline Holothurians & 6.677 & 0.934 & 0.05 & 0.08 & 0.257 & 0.06 & 0.13 & 0.094 & 0.692 & 0.05 & 0.06 \\
\hline Brittlestars & 3.394 & 0.486 & 0.05 & 0.11 & 0.909 & 0.08 & 0.24 & 0.17 & 0.475 & 0.05 & 0.07 \\
\hline Echinocardium cordatum & 5.024 & 0.157 & 0.05 & 0.09 & 0.652 & 0.07 & 0.19 & 0.394 & 0.086 & 0.05 & 0.06 \\
\hline
\end{tabular}


niles of other taxa. Nonetheless, the results are consistent with those of 2 other studies that have examined the effects Sabella on infauna. O'Brien et al. (2006) recorded no effects of Sabella clumps on infaunal colonisation, concluding that effects on infauna appear to be driven via post- rather pre-colonisation processes. D. J. Ross et al. (unpubl. data) detected only one significant effect of Sabella on infauna despite a high Sabella density ( $>5$ ind. $\mathrm{m}^{-2}$ ) and a 12 mo experimental period that incorporated infaunal recruitment.

Overall, our results show that, with the exception of lumbrinerid polychaetes and gammarid amphipods, Sabella had no effect on the resident macrofauna.
Even though the treatment density of Sabella had declined by the end of the experiment, the range of densities was sufficient to produce maximum densities equivalent to, and for the most part, greater than those recorded in a recent survey of Sabella distribution in Port Phillip Bay (Hart et al. 2004). Of the 78 sites surveyed by divers and with towed video, the density of Sabella was $<1$ ind. $\mathrm{m}^{-2}$ at all but 3 sites where it was recorded at $1.2,1.8$ and 7.65 ind. $\mathrm{m}^{-2}$ (Hart et al. 2004). The results of this study indicate that effects of Sabella on soft sediment assemblages at these densities are likely to be negligible. The results also suggest negligible effects at the higher densities a) Sabella density $\left(m^{-2}\right)$

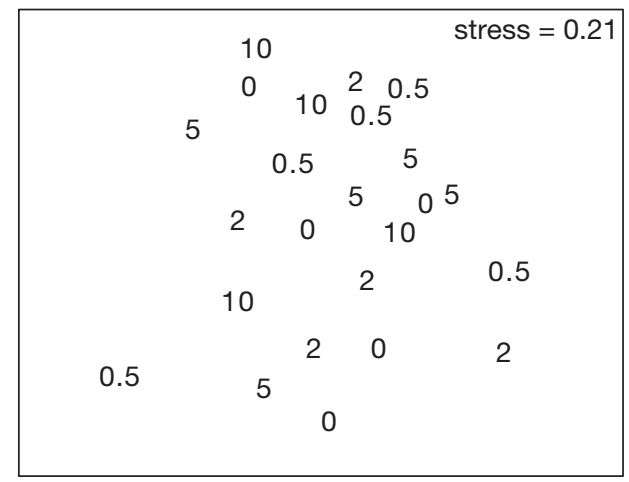

b) Styela density $\left(\mathrm{m}^{-2}\right)$

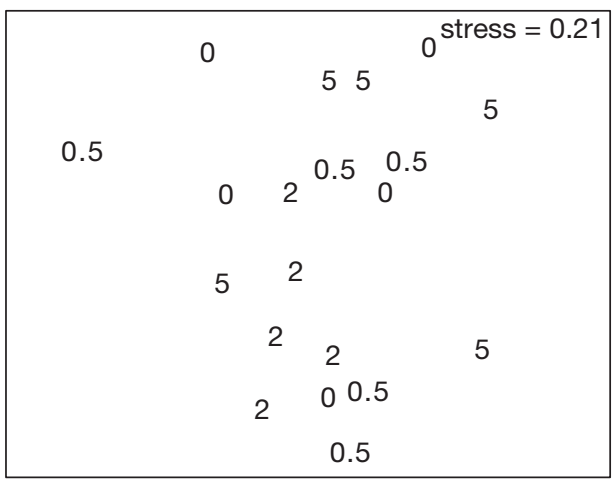

Fig. 3. Ordination (MDS) of the infaunal assemblage in (a) Sabella spallanzanii and (b) Styela clava treatments. Labels correspond to the density (initial) in each plot

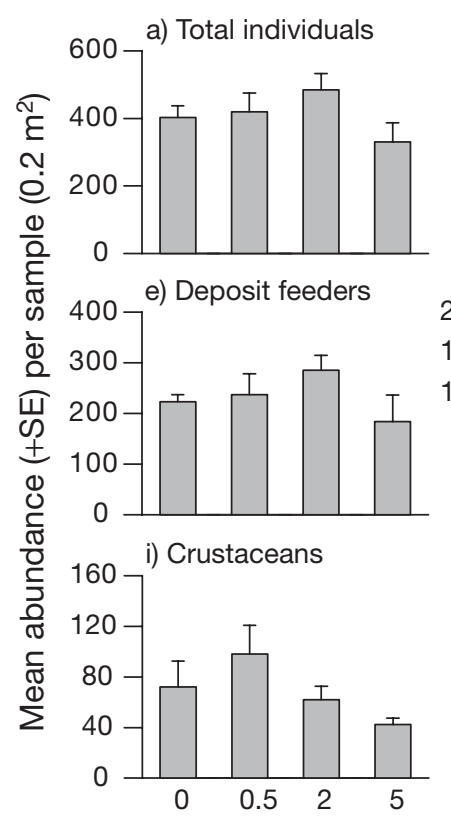

b) Total species
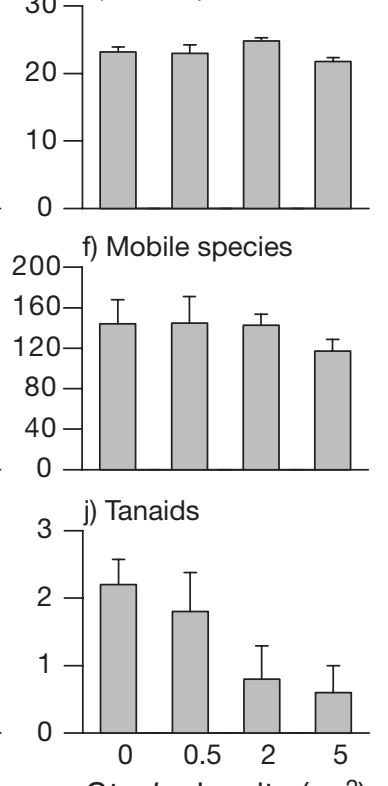

c) Species diversity
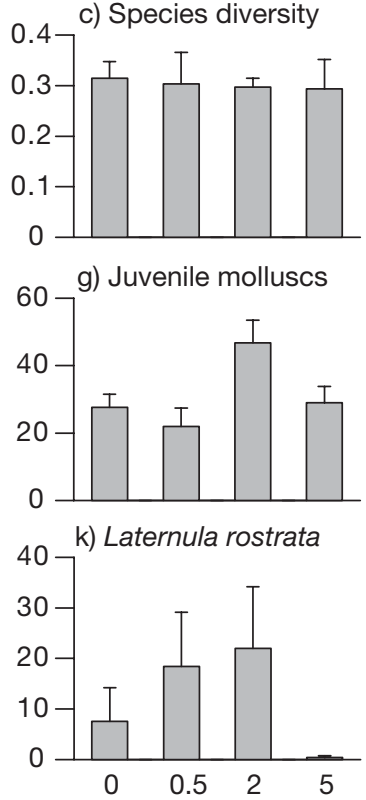

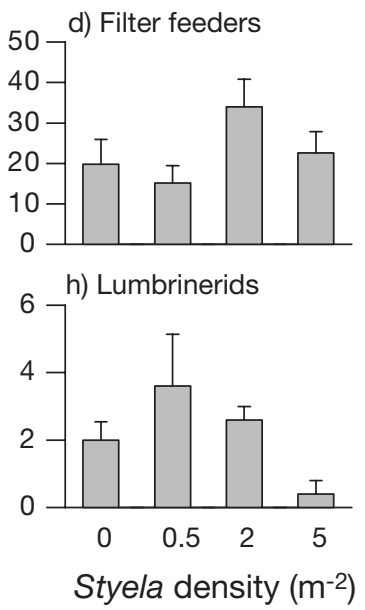

Styela density $\left(\mathrm{m}^{-2}\right)$

Fig. 4. Styela clava. Mean abundances + SE per sample $\left(0.2 \mathrm{~m}^{2}\right)$ of the major taxa and groups found in each Styela density treatment 


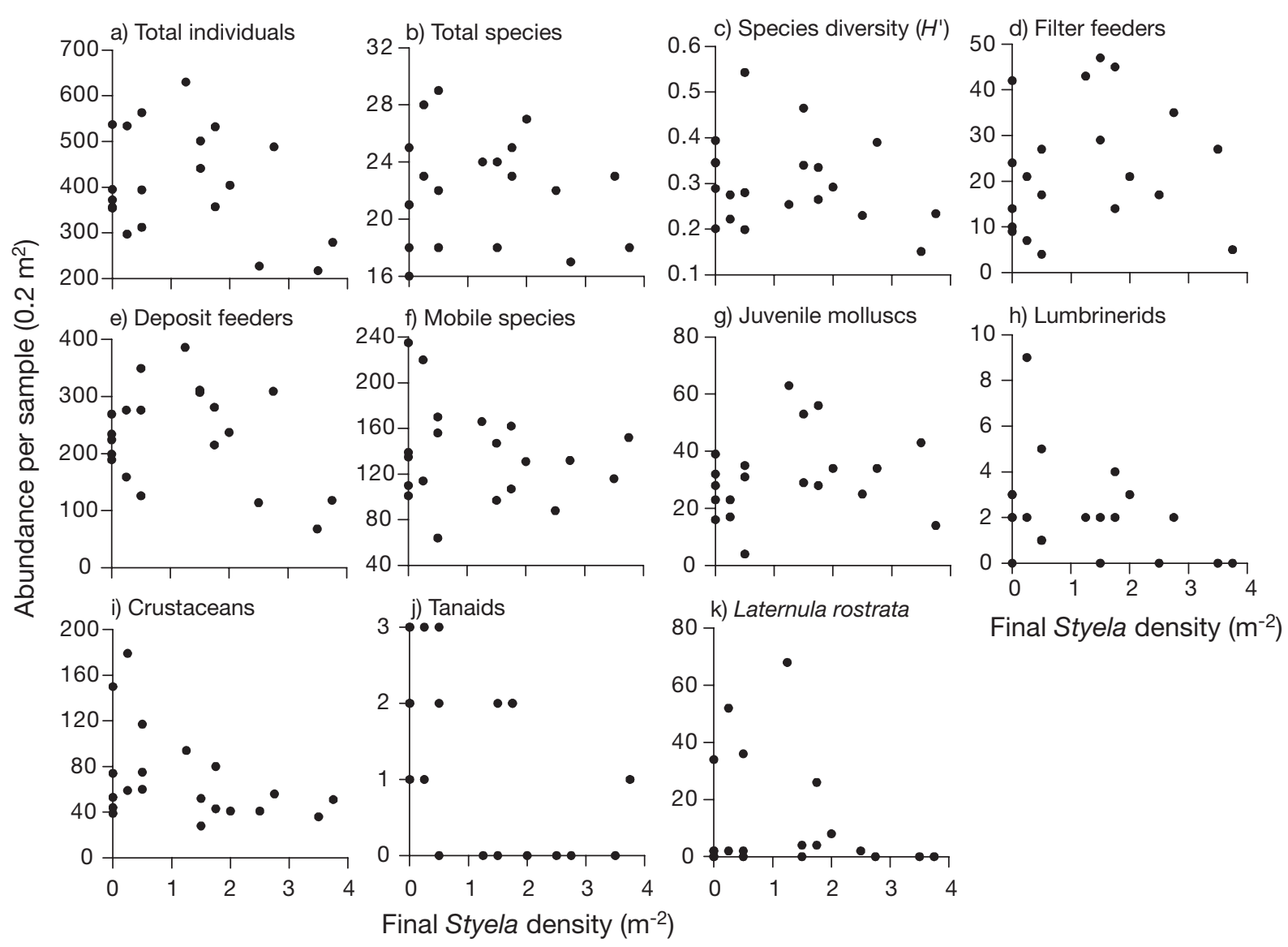

Fig. 5. Styela clava. Abundance per sample $\left(0.2 \mathrm{~m}^{2}\right)$ of the major taxa and groups against the final density of Styela in each experiment plot

recorded following the initial establishment and expansion of Sabella in the late 1980s to mid-1990s (1 to 5 ind. $\mathrm{m}^{-2}$, Parry et al. 1996) given that the densities recorded by Parry et al. (1996) still fall within the range of treatment densities. On hard substrates, where Sabella densities are typically much higher, Holloway \& Keough (2002a) also found little evidence that Sabella affected established assemblages despite generally good power in their tests and a treatment density $\sim 250$ Sabella $\mathrm{m}^{-2}$. In our study the power to detect a 50 or $80 \%$ change in abundance between the control and 10 Sabella $\mathrm{m}^{-2}$ was low for some of the taxa and groups. While this suggests that little weight can be given to these results, it is worth considering that an $80 \%$ change in abundance between the control and 10 Sabella $\mathrm{m}^{-2}$ equates to an $8 \%$ change at 1 Sabella $\mathrm{m}^{-2}$ (assuming a linear effect of density) which is at the upper end of densities typically recorded (Cohen et al. 2000, Hart et al. 2004, D. J. Ross unpubl. data). From a management perspective, a change of this magnitude is not likely to warrant a response. On the other hand, a 50 or $80 \%$ change to resident macrofauna at current densities may trigger a management response, in which case, we have sufficient power $(\geq 0.8)$ for the majority of taxa and groups.

Despite lower power to detect treatment effects, Styela had a greater effect on resident macrofauna than Sabella. These effects were on individual taxa and one composite group (crustaceans) rather than any of the macrofaunal groups for which we had made $a$ priori predictions, despite good power for the latter. The lack of any responses by these groups indicates that the processes (e.g. competition for food, predation) that we suggested may be associated with Styela (or Sabella) are not having an overriding influence on macrobenthic assemblages. It seems more likely that responses (or lack thereof) are due to more subtle differences in the requirements of individual species (see Hanson 1990, Gee \& Warwick 1995). Nonetheless, there did appear to be a decline in the abundance of small mobile surface dwelling crustaceans (tanaids, mysids and cumaceans) at the highest Styela density. There are a variety of different mechanisms that may produce this pattern. For instance, because they live and feed right at the sediment-water interface, they 
may be more sensitive to changes (e.g. sediments, food etc.) due to altered hydrodynamic conditions. These changes may lead to either emigration from Styela plots and/or differential survivorship between plots with and without Styela. Irrespective of whichever factor or factors produced the observed declines in abundance, it is worth considering the effect sizes in context of current Styela densities in Port Phillip Bay (0 to 0.2 ind. $\mathrm{m}^{-2}$, Cohen et al. 2000, D. J. Ross pers. obs.). The results suggest that changes in the abundance of macrofauna are only likely to be substantial at densities of $>1$ ind. $\mathrm{m}^{-2}$, but patches of Styela at this density are not common and usually cover relatively small areas ( 1 to $10 \mathrm{~m}^{2}$ ) (Cohen et al. 2000, D. J. Ross pers. obs.).

The predictions we made at the onset of this experiment were based on the results of previous studies on species capable of having effects on benthic assemblages via their biological activities, in this case, suspension feeding and/or their physical presence in the habitat (e.g. Woodin 1976, Hines et al. 1989, Crooks 1998, Cummings et al. 2001). While the results for Styela were not necessarily in line with our predictions, it was the lack of significant effects of Sabella spallanzanii on macrofauna that was surprising. At densities of 5 and 10 ind. $\mathrm{m}^{-2}$ they constitute a dominant structural aspect on an otherwise fairly featureless soft sediment habitat given the size of the tube (5 to $15 \mathrm{~mm}$ in diameter and 20 to $30 \mathrm{~cm}$ in length) and diameter of the feeding fan $(10$ to $15 \mathrm{~cm})$. However, in comparison to the density and/or complexity of suspension feeders in the studies that have reported significant effects on benthic assemblages, the density and complexity of Sabella in our study seems relatively low. For example, the effects reported for the suspension feeding mytilid mussels (e.g. Crooks \& Khim 1999, Ragnarsson \& Raffaelli 1999) and tube-building suspension feeders (Woodin 1976, Brenchley 1982, Levin 1982) are typically at densities of 1000 s ind. $\mathrm{m}^{-2}$ which create dense mats or carpets. Similarly, effects of the large ( $10 \mathrm{~cm}$ long and $7 \mathrm{~cm}$ wide) suspension feeding bivalve Atrina zelandica were predominately at high (75 ind. $\mathrm{m}^{-2}$ ) rather than low (7.5 ind. $\mathrm{m}^{-2}$ ) densities (Cummings et al. 2001). Interestingly, O'Brien et al. (2006) examined the effect of Sabella in localised dense patches (clumps of 10 or more ind.) and reported changes to the abundance of taxa, particularly surface dwelling crustaceans, in the sediments directly under the clumps. The network of tubes in the clumps also provided a habitat for a range of sessile and mobile invertebrates. However, it is not known whether the clumps lead to larger scale effects beyond the sediments directly underneath.

In a review of soft sediment community ecology, Lenihan \& Micheli (2001) suggest that soft sediment fauna do not commonly attain the densities high enough to render space limiting. They also suggest that competition for food does not seem to result in the disappearance of species or death of individuals, but rather more subtle effects, such as reduction of growth and reproductive effects. In their study on Sabella impacts on hard substrates, Holloway \& Keough (2002a) reported significant effects on growth rates of epifaunal taxa despite few effects on the abundances of epifauna. Although our results suggest that Sabella effects on the abundance of soft sediment fauna are likely to be negligible at the densities typically recorded on Port Phillip Bay sediments, they may be having more subtle and potential long term effects.

The number of published studies that have examined the impacts of introduced species in the marine environment has increased dramatically in the last 10 years (see Grosholz 2002). Although a large proportion of introduced species are likely to have negligible ecological impacts (Carlton \& Geller 1993, Williamson 1996, Ruiz et al. 1999) the literature is dominated by studies documenting negative effects, and to a lesser extent, positive effects on native species (e.g. Crooks 1998, 2002b, Wonham et al. 2005). We suggest that this may not be a true reflection of the magnitude or direction of invader impacts, but rather, under-reporting of non-significant results. In some cases this may reflect a lack of statistical power, and hence confidence, in tests for invader impacts. In our study, we provide evidence that the introduced polychaete Sabella had a negligible effect on resident macrofauna despite sufficient power for a large number of taxa and composite groups and treatment densities that cover the range of densities recorded on soft sediments since its establishment in Port Phillip Bay. Similarly, Holloway \& Keough (2002a) found little to indicate that Sabella affected established assemblages on hard substrates despite good power in their tests and a treatment density $\sim 250$ Sabella $\mathrm{m}^{-2}$. Whilst it would be inappropriate to make broad generalisations about the effects of Sabella on hard and soft substrates throughout Port Phillip Bay based on single site/time experiments (e.g. Ruiz et al. 1999, Cummings et al. 2001) the results of these 2 studies highlight the uncertainty of inferring an invader's impact on the basis of its density and a limited knowledge of its ecology. In terms of prioritising management efforts, quantitative assessment of real impacts is imperative to assess the risk of ecological damage from these species.

Acknowledgements. We thank Dustin Marshall, Simon Hart, Matt Reardon, Rod Watson, Rachael Bathgate, John Ahern and Elisa Bone for their invaluable assistance in the field. Special thanks go to Allyson O'Brien for help in the field and tireless hours of sorting samples. This study was supported by an ARC Linkage grant to M.J.K., A.R.L., and J. Klemke. 


\section{LITERATURE CITED}

Andre C, Jonsson PR, Lindegarth M (1993) Predation on settling bivalve larvae by benthic suspension feeders: the role of hydrodynamics and larval behaviour. Mar Ecol Prog Ser 97:183-192

Brenchley GA (1982) Mechanisms of spatial competition in marine soft-bottom communities. J Exp Mar Biol Ecol 60: 17-33

Bruno JF, Bertness MD (2001) Habitat modification and facilitation in benthic marine communities. In: Bertness MD, Gaines SD, Hay EM (eds) Marine community ecology. Sinauer Associates, Sunderland, MA, p 201-218

Carey JM, Keough MJ (2002) Compositing and subsampling to reduce costs and improve power in benthic infaunal monitoring programs. Estuaries 25:1053-1061

Carey JM, Watson JE (1992) Benthos of the muddy bottom habitat of the Geelong Arm of Port Phillip Bay, Victoria, Australia. Victorian Naturalist 109:196-202

Carlton JT (1989) Man's role in the changing face of the ocean: biological invasions and implications for conservation of near-shore environments. Conserv Biol 3:265-273

Carlton JT, Geller JB (1993) Ecological roulette: the global transport of nonindigenous marine organisms. Science 261:78-82

Clarke KR (1993) Non-parametric multivariate analysis of changes in community structure. Aust J Ecol 18:117-143

Cohen BF, Currie DR, McArthur MA (2000) Epibenthic community structure in Port Phillip Bay, Victoria, Australia. Mar Freshw Res 51:689-702

Crooks JA (1998) Habitat alteration and community-level effects of an exotic mussel, Musculista senhousia. Mar Ecol Prog Ser 162:137-152

Crooks JA (2002a) Characterizing ecosystem-level consequences of biological invasions: the role of ecosystem engineers. Oikos 97:153-166

Crooks JA (2002b) Predators of the invasive mussel, Musculista senhousia. Pac Sci 56:49-56

Crooks JA, Khim HS (1999) Architectural vs. biological effects of a habitat-altering, exotic mussel, Musculista senhousia. J Exp Mar Biol Ecol 240:53-75

Cummings VJ, Thrush SF, Hewitt JE, Funnell GA (2001) Variable effect of a large suspension-feeding bivalve on infauna: experimenting in a complex system. Mar Ecol Prog Ser 209:159-175

Eckman JE (1983) Hydrodynamic processes affecting benthic recruitment. Limnol Oceanogr 28:241-257

Elton CS (1958) The ecology of invasions by animals and plants. Methuen, London

Gee JM, Warwick RM (1995) Body-size distribution in a marine metazoan community and the fractal dimensions of macroalgae. J Exp Mar Biol Ecol 178:247-259

Green MO, Hewitt JE, Thrush SF (1998) Seabed drag coefficient over natural beds of horse mussels (Atrina zelandica). J Mar Res 56:613-637

Greilach P, You Z, Black K, Gorman R (1997) Sediment characteristics in Port Phillip Bay. Technical report No. 23, Port Phillip Bay Environmental Study. CSIRO Projects Office, Dickson, Australian Capital Territory

Grosholz ED (2002) Ecological and evolutionary consequences of coastal invasions. Trends Ecol Evol 17:22-27

Grosholz ED, Riuz GM, Dean CA, Shirley KA, Maron JL, Connors PG (2000) The impacts of a nonindigenous marine predator in a California bay. Ecology 81:1206

Hanson JM (1990) Macroinvertebrate size-distributions of two contrasting freshwater macrophyte communities. Freshw Biol 24:481-492
Hart S, Edmunds M, Elias J, Power B (2004) Port Phillip Bay Channel Deepening Project environmental effects statement-Marine Ecology Specialist Studies. Vol 5: Seagrass and sediment biota. Report to the Port of Melbourne Corporation and Parsons Brinckerhoff. Australian Marine Ecology Report 162, Melbourne

Hewitt CL, Campbell ML, Thresher RE, Martin RB and 15 others (2004) Introduced and cryptogenic species in Port Phillip Bay, Victoria, Australia. Mar Biol 144:183-202

Hines AH, Posey MH, Haddon PJ (1989) Effects of adult suspension- and deposit-feeding bivalves on recruitment of estuarine infauna. Veliger 32:109-119

Holloway MG, Keough MJ (2002a) Effects of an introduced polychaete, Sabella spallanzanii, on the development of epifaunal assemblages. Mar Ecol Prog Ser 236:137-154

Holloway MG, Keough MJ (2002b) An introduced polychaete affects recruitment and larval abundance of sessile invertebrates. Ecol Appl 12:1803-1823

Holmes NJ (1976) Occurrence of the ascidian Styela clava Herdman in Hobsons Bay, Victoria: A new record for the southern hemisphere. Proc R Soc Vic 88:115-116

Klerks PL, Fraleigh PC, Lawniczak JE (1996) Effects of zebra mussels (Dreissena polymorpha) on seston levels and sediment deposition in western Lake Erie. Can J Fish Aquat Sci 53:2284-2291

Lenihan HS, Micheli F (2001) Soft-sediment communities. In: Bertness MD, Gaines SD, Hay ME (eds) Marine community ecology. Sinauer Associates, Sunderland, MA, p 253-287

Levin LA (1982) Interference interactions among tube dwelling polychaetes in a dense infaunal assemblage. J Exp Mar Biol Ecol 65:107-119

Micheli F (1997) Effects of predators foraging behaviour on patterns of prey mortality in marine soft bottoms. Ecol Monogr 67:203-224

Nichols FH, Thompson JK, Schemel LE (1990) Remarkable invasion of San Francisco Bay (California, USA) by the Asian clam Potamocorbula amurensis. II. Displacement of a former community. Mar Ecol Prog Ser 66:95-101

O'Brien AL, Ross DJ, Keough MJ (2006) Effects of the physical structure of an introduced polychaete, Sabella spallanzanii on macrofauna in soft sediments. Mar Freshw Res 57: $363-371$

Parry GD, Lockett MM, Crookes DP, Coleman N, Sinclair M (1996) Mapping and distribution of Sabella spallanzanii in Port Phillip Bay. Project 94/164, Victorian Fisheries Research Institute, Queenscliff, Victoria

Petersen JK, Riisgard HU (1992) Filtration capacity of the ascidian Ciona intestinalis and its grazing impact in a shallow fjord. Mar Ecol Prog Ser 88:9-17

Peterson CH, Black R (1987) Resource depletion by active suspension feeders on tidal flats: influence of local density and tidal elevation. Limnol Oceanogr 32:143-166

Peterson CH, Black R (1993) Experimental tests of the advantages and disadvantages of high density for 2 coexisting cockles in a Southern Ocean lagoon. J Anim Ecol 62: 614-633

Peterson CH, Heck KL (1999) The potential for suspension feeding bivalves to increase seagrass productivity. J Exp Mar Biol Ecol 240:37-52

Ragnarsson SA, Raffaelli D (1999) Effects of the mussel Mytilus edulis L. on the invertebrate fauna of sediments. J Exp Mar Biol Ecol 241:31-43

Ross DJ, Johnson CR, Hewitt CL (2002) Impact of introduced seastars Asterias amurensis on survivorship of juvenile commercial bivalves Fulvia tenuicostata. Mar Ecol Prog Ser 241:99-112 
Ross DJ, Johnson CR, Hewitt CL (2003) Variability in the impact of an introduced predator (Asterias amurensis: Asteroidea) on soft-sediment assemblages. J Exp Mar Biol Ecol 288:257-278

Ruiz GM, Carlton JT, Grosholz ED, Hines AH (1997) Global invasions of marine and estuarine habitats by non-indigenous species: mechanisms, extent, and consequences. Am Zool 37:621-632

Ruiz GM, Fofonoff P, Hines AH, Grosholz ED (1999) Nonindigenous species as stressors in estuarine and marine communities: assessing invasion impacts and interactions. Limnol Oceanogr 44:950-972

Shushkina E, Musayeva E (1990) Structure of the plankton community from the Black Sea and its changes as a result of the introduction of a ctenophore species. Oceanography 30:225-228

Snelgrove PVR, Butman CA, Grassle JP (1993) Hydrodynamic enhancement of larval settlement of the bivalve Mulinia lateralis and the polychaete Capitella S. 1 in microdepositional environments. J Exp Mar Biol Ecol 168:71-109

Editorial responsibility: John Gray (Contributing Editor), Oslo, Norway
Talley TS, Crooks JA, Levin LA (2001) Habitat utilization and alteration by the invasive burrowing isopod, Sphaeroma quoyanum, in California salt marshes. Mar Biol 138: 561-573

Thresher RE (1999) Key threats from marine bioinvasions: a review of current and future issues. In: Pederson J (ed) Marine bioinvasions. MIT Press, Cambridge, MA, p 24-34

Vitousek PM, D'Antonio CM, Loope LL, Westbrooks R (1996) Biological invasions as global environmental change. Am Sci 84:468-478

Williamson M (1996) Biological invasions. Chapman \& Hall, London

Wonham MJ, O'Connor M, Harley CDG (2005) Positive effects of a dominant invader on introduced and native mudflat species. Mar Ecol Prog Ser 289:109-116

Woodin SA (1976) Adult-larval interactions in dense infaunal assemblages: patterns and abundance. J Mar Res 34: $25-41$

Woodin SA (1978) Refuges, disturbance, and community structure: a marine soft-bottom example. Ecology 59:274-284

Submitted: December 9, 2005; Accepted: October 11, 2006 Proofs received from author(s): May 28, 2007 